\title{
DAM FOUNDATION TREATMENT: HIGH STRESS WATETIGHTNESS
}

\author{
Maha Ben Tahar ${ }^{1, *}$, Lahcen Bahi ${ }^{1}$ and Latifa Ouadif ${ }^{1}$ \\ 13GIE Laboratory, Mohammadia Engineering School, Mohammed V University, Rabat, Morocco
}

\begin{abstract}
By its dual function of consolidation and sealing, injection treatment is the most appropriate process to solve the majority of problems in the most diverse soils. Concerning a foundation, the use of this treatment makes it possible to reduce or eliminate karst risks by taking into account the geological implications of each region. However, its effectiveness is difficult to measure, especially when it comes to the treatment of a dam site where the waterthigtness of the foundation is essential for overall stability. A control of the parameters that regulate the injectability of the karst as well as a good knowledge of the karst environment allows the correct evaluation of the nature of the products and the methods of implementation of the grout curtain guaranteeing the safety of the structure. It is from this perspective that a statistical study of karst anomalies was carried out on the foundation of El Ghrass dam in order to define an adequate distribution of these karsts, which is essential for the determination of the pattern of injection (drilling spacing, alignments) necessary for the preparation of the quantities of the injection market.
\end{abstract}

\section{Introduction}

The watertightness of dams is generally ensured by the construction of an injection curtain under the structure called « grout curtain » [1].

In particular the watertightness of El Ghrass dam is a rather complex problem since it is entirely located in the limestones of the Aaleno-Bajocian seating of a karst activity which may endanger the stability of the foundation, and makes it difficult to choose the injection parameters and especially the mesh and the extension of the sealing veil, that must be adapted to the nature of the foundation [2].

\section{Site Geology}

The dam site is founded on Oued Za, a tributary of Oued Moulouya, situated at $33 \mathrm{Km}$ as the crow flies to the south- east of the town of Taourirt, at the western end of a collapse zone (El Hai Graben) itself limited to the north and north east by the Jerrada mountains and horsts, and to the south by those of Mekkam dome where the primary age basement expose.

On a regional scale, the old folded Granitic Paleozoic outcrop can be seen at $5 \mathrm{Km}$ south of the site and $10 \mathrm{Km}$ further north, it is associated to the Triassic clays and basalts forming a waterproofing barrier and on which is overlying the Jurassic dolomitic limestone series affected essentially by a faulting tectonic. The Mio-Pliocene and Quaternary formations form the last overlaps on the previous series.

On this site, the river has a WNW direction and dug a transverse valley through a rather anticlinal structure with internal folds.

The entry of the river's gorges have a very steep dipping of the layers of 70 to $80^{\circ}$ upstream, forming the limb of an asymmetric anticlinal fold slightly lying upstream with an axis directed NNE and an azimuth of 15 to $20^{\circ}$. The downstream limb of this anticlinal is almost horizontal over 50 to $60 \mathrm{~m}$ and then falls back into an acute synclinal where the layers become almost horizontal over about $200 \mathrm{~m}$ to form again an acute limbs anticlinal $\left(50-70^{\circ}\right)$ downstream.

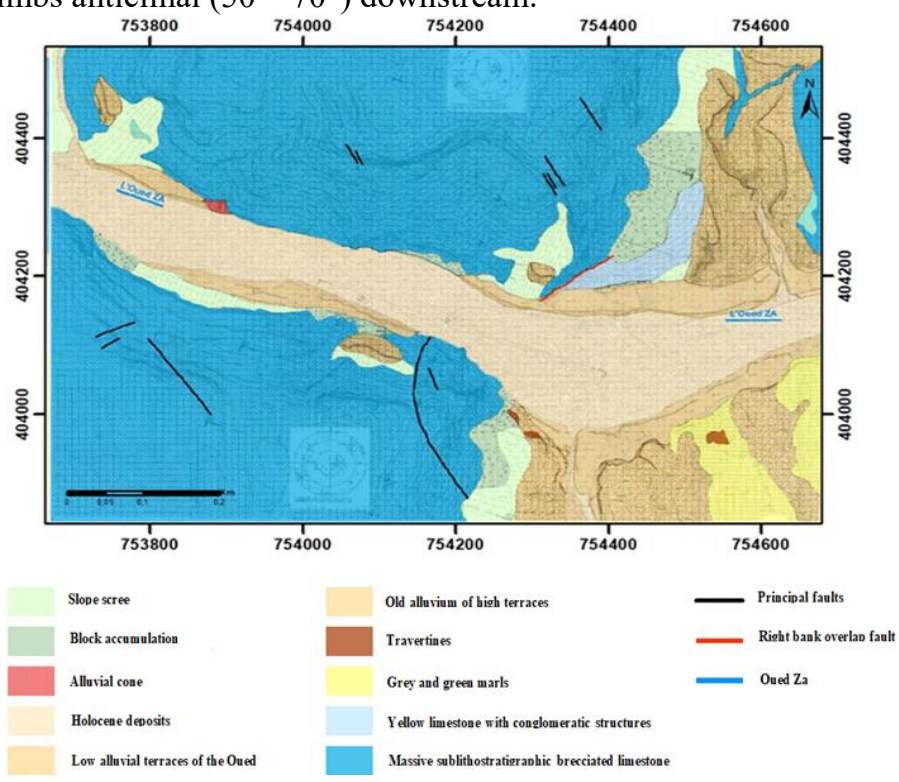

Fig. 1. 1/1000 Geological map of El GHRASS dam [3]

The structure of El Ghrass dam appear to be more complicated, and presents a sequence of anticlinal and synclinal folds of decametric extent generally affected by several fault and fracture systems. In addition to the surface geological data, the stratigraphy and structure of the dam site is based on the interpretation of geotechnical data from exploration drillings and geophysical data result of refraction shooting. According to those results, the sedimentary series of the site area

Corresponding author: Mahabentahar@gmail.com 
are classified into six units which are from the top to the bottom:

-The AalenoBajocian limestone series, which concerns the entire dam area.

- Cornstone limestone and fossiliferous marls of the Bathonian.

-The Tertiary (MioPliocene) lacustrine continental sediments series that only outcrops upstream of the site: it is a powerful series of silts, clays and red marls divided with thin conglomeratic layers at the top.

- The ancient Quaternary is represented by the remains of old alluvial terraces upstream of the site and in the reservoir: they are beige silts, sands and gravels.

- The recent Quaternary is represented by:

- Slope deposits of colluvium and scree more or less incrusted.

- The travertine deposits upstream of the site testify to a period of limestone drainage by large springs in a high level of erosion.

- Finally, the recent coarse alluvial deposits and the low sandy-silty terraces of the oued.
A morphology of a transverse valley, dug to a complex anticlinal structure with internal folds in the sides of the site. The entrance of the gorges formed by the anticline fold of the very steep upstream flank and intersected by an altitude fault $\left(305-310 / 50^{\circ}\right)$ which brings the horizontal marl layers of the Bathonian, into contact with the limestones on the site.

- In the upstream part of the gorges of the site, or dam area and its associated structures, the series of anticlinal and synclinal folds that follow the main upstream fold gives a significant variation in the dip in the upstream-downstream direction, successively changing to upstream and downstream plunges that vary according to the situation in the folds. But the axial planes of the various folds remain transverse to the valley.

- The valley bottom, about $90 \mathrm{~m}$ wide, is filled with recent coarse alluvium from the major bed of the oued. At the local edge remains a narrow strip of low silt sandy-gravelly alluvial terrace.
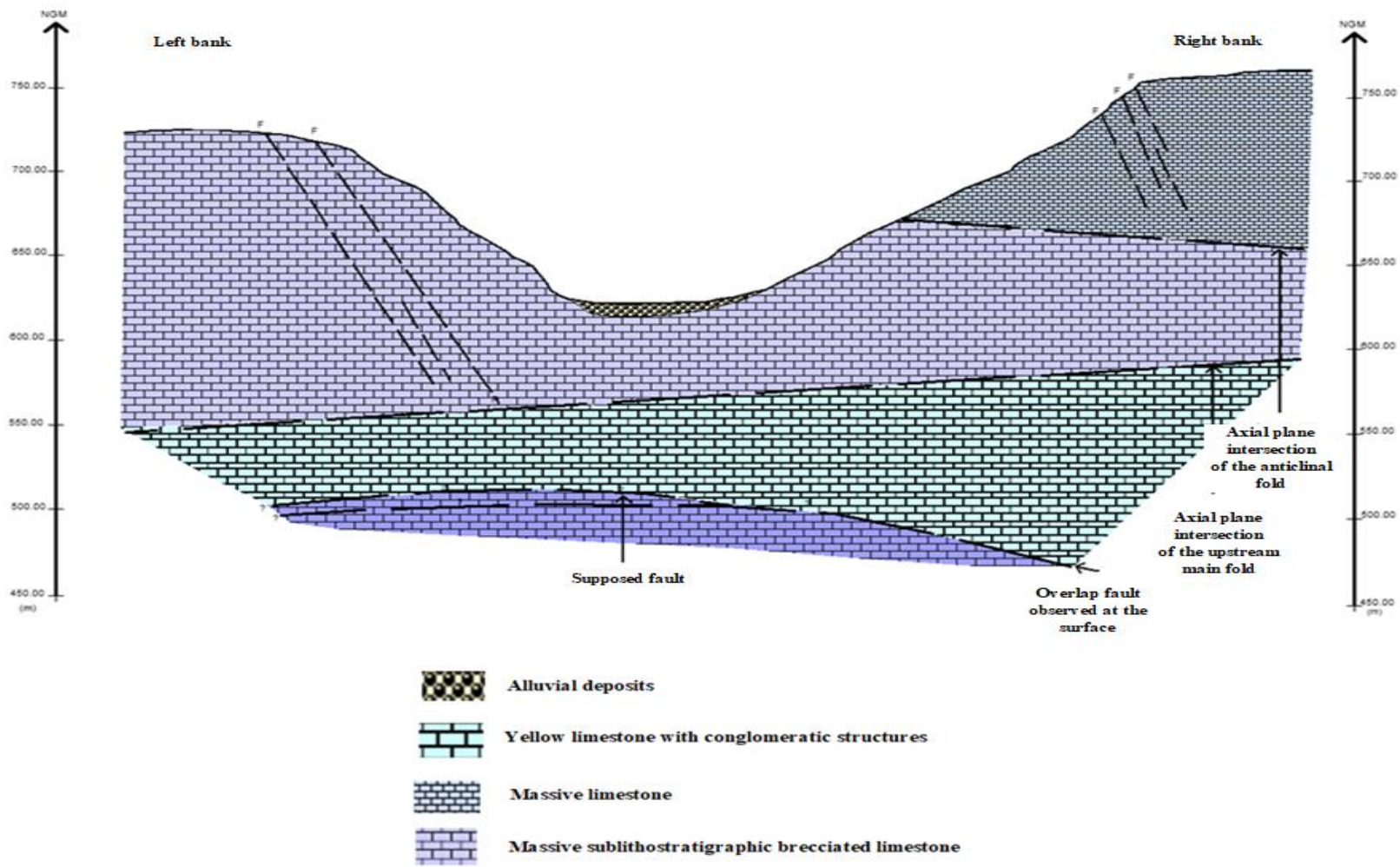

Fig. 2. Geologic section downstream-upstream of dam's El Ghrass

However, detailed surface mapping at the excavation level has shown a more pronounced lithology, we find:

- Two banks entirely formed by Aaleno Bajocian limestones, a series of limestones in slab of 0.1 to $0.5 \mathrm{~m}$ thick, which can reach 1 to $2 \mathrm{~m}$ in places. These limestones banks can be separated by thin marl levels up to $10 \mathrm{~cm}$ thick.
Systematic measurements of folds and fractures were taken on the two banks of the site, and were reported on the Schmidt net in the lower hemisphere. The distribution of the poles on this net makes it possible to mark different fracture systems:

- S: Orientation of the layers, the distribution of the poles indicates the same type of folds on both banks of the site (axis of the fold N-S with a direction of $30^{\circ}$ north) they are inclined folds with an axial plane of a $\mathrm{W}$ or E plunge). 
- A1: main fracture system, including a main fault system observed in the cliffs on both banks of the site, and in the limestone block (N140$\left.150^{\circ} \mathrm{E}\right)$.

- A2: counter fracture system of the previous one.

-B1, B2: Main system and counter system of fractures. The poles of these systems are mostly concentrated on the left bank, while on the right bank; the distribution of these fractures is much more diffuse with a direction of $90^{\circ}$ north.

- F: overlap upstream fault located in the right bank with a direction of $\mathrm{N} 40-50^{\circ} \mathrm{NW}$. it is not due to a fracture system and is characterized by a different altitude.
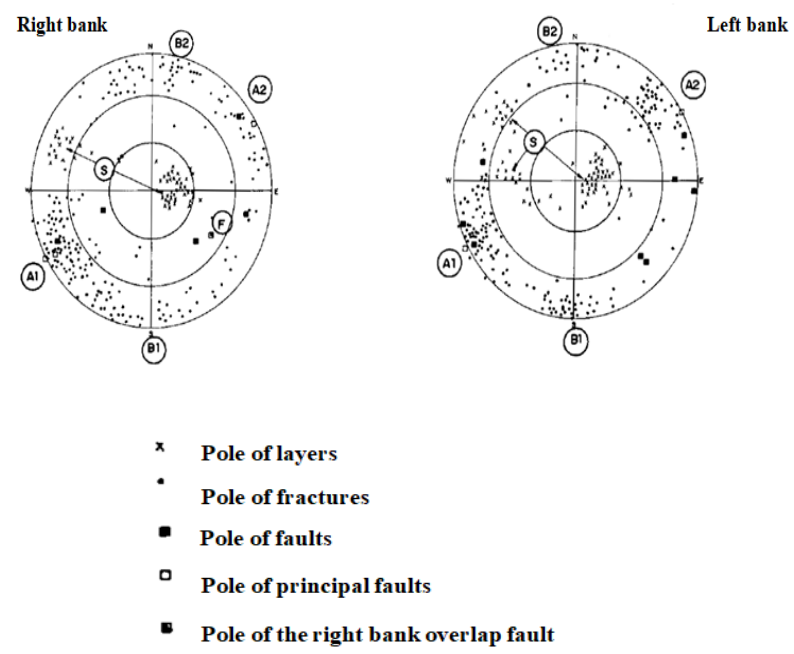

Fig. 3. Fracture plotting

on the Schmidt net inthe lower hemisphere

The analysis of 245 measurements of fracturing at the bottom of the dam excavations and prospecting galleries reported on the lower hemisphere of Schmidt net (Figure 2) shows the two fracture systems A and B.

Close observation of the excavation bottom shows the shearing character of these two fracture systems, which combined with stratification are most often the major structural guides to karst development.

A statistical analysis of the main characteristics of the fractures was carried out and showed that these fractures are rarely continuous, and without significant throw, they are therefore diaclases with a regular frequency of about 1 to $2 \mathrm{~m}$.

The characteristics of the contact surfaces show a clear statistical difference the two banks of the dam:

- On the right bank: the contact surfaces are mostly rough $(65 \%)$, less smooth $(28 \%)$, very rarely clayfilled $(6 \%)$ or with sliding mirror $(2 \%)$.

- On the left bank: the surfaces are often smooth and rough (36\%) and frequently clay-filled $(27 \%=$ Clear sliding mirrors are still rare.)

The left bank therefore appears more strongly tectonized as also shown by the presence of very compressed minor folds.

\subsection{Problems related to the karst limestones of the Aaleno-Bajocien}

The site and the reservoir are situated in the complex of Aaleno-Bajocien sublithostratigraphic limestones which is a massive decametric to metric bank, separated by centimetric marly clayey joints (from 1 to $10 \mathrm{~cm}$ thick). Their base is not known, it has not been reached by the deepest holes of $150 \mathrm{~m}$, of a significant total thickness, and rest in depth on the series of red marls with granular limestones of the Toarcien.

These limestones are locally karstified [4]. This karstification is often filled with a clayey-silt material, developing mainly along fractures and in folded areas.

In addition to the presence of an active drainage network in the limestone massif drained by the fracturing and faulting system $\mathrm{A}$, and the flow of the karst groundwater offshore parallel to the Oued $\mathrm{Za}$, which accentuates the problem of possible losses to the immediate dam supports and especially at the foot of the right bank.

Geological surveys as well as excavations of the dam and galleries dug in these limestones were the subject of several in order to identify karsts networks [5], to study their genesis and structural control in order to better orient their investigation and treatment in depth as well as their impact on the definition of the dam's grout curtain [6].

\section{Material and methods:}

The sedimentary structure in the map of the grout curtain is defined by the different folds and faults intercepted by this plane, and its useful for research, treatment and structural controls of the karstification of the site [7-8].

To better study karst networks, it is proposed first to qualitatively study the various karsts identified in the excavated areas: excavations of the dam, underground galleries and access roads to the site, determine the geometry of the karsts (vertical, horizontal and communication between them), the nature of their filling and estimate the influence of other structural elements (such as faults, fractures) on the location/orientation of karst pipes.

Then, a statistical study will refine the design of the grout curtain to better intercept karst anomalies and define the right mesh and inclination of the injections wells, a device that will guarantee a good waterproofing of the dam foundation [9].

\subsection{Karst distribution and geometry}

Observations made over $1400 \mathrm{~m}$ of prospecting galleries revealed 45 anomalies or karstic zones of $20 \mathrm{~cm}$ large, which approximately equals one hole every $22 \mathrm{~m}$.

The most karst areas [10-11] consist of inframetric ducts whose orientation is mainly related to tectonic structures, the two main systems A and B and the stratification, and which constitute the major structural guides for karst development. As a result, regional karst flows can be divided between a return to Oued $\mathrm{Za}$ and an 
offshore recharge of groundwater on both banks of the river. In this context, we find:

- Vertical ducts mainly in the rainwater absorption zone, they are very numerous and of very small dimensions.

- Ducts of larger dimensions in the transfer zone, where the flow is also vertical. These two zones are of quaternary and contemporary age.

- Prequaternary age ducts in the restitution zone more or less horizontal or slightly inclined, less numerous and of larger dimensions than the dimensions of the previous zones.

We can therefore distinguish two families of karsts (figure 3):

-Family 1: vertical ducts of quaternary age with hole diameters less than $2 \mathrm{~m}$.

- Family 2: horizontal or slightly inclined ducts of Prequaternary age with a hole diameter greater than $2 \mathrm{~m}$.

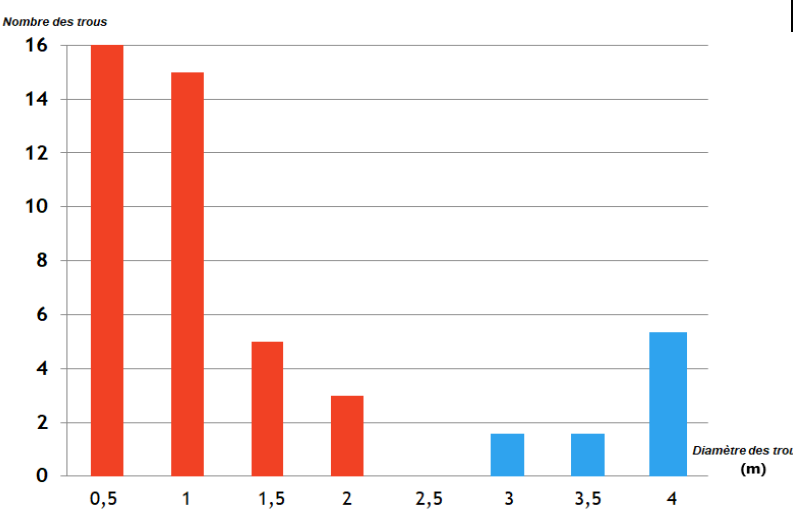

Fig. 4. Workforce diagram- diameters of karst holes

\subsection{Karst filling materials}

The filling of karst anomalies is much diversified, the most frequent being observed mainly in medium-sized cavities. They are of the type:

- Tuffaceous sandstone, slightly to moderately cemented, locally sandy, sometimes moderately clayey.

- These deposits are generally heterogeneous, and very rarely stratified.

- Clayey-gravel, well layered into parallel flat laminates.

- Purely clayey, very rare and in $50 \%$ of cases, clay is plastic.

The red or black color of these materials corresponds mainly to the accumulation of insoluble clayey residues, and the chemical analyses carried out confirm the predominance of silico-aluminous products (Table1):

\begin{tabular}{|c|c|c|c|c|c|}
\hline $\begin{array}{c}\text { Anomali } \\
\text { es : }\end{array}$ & $\begin{array}{c}\text { Localisati } \\
\text { on : }\end{array}$ & $\begin{array}{c}\text { CaC } \\
\mathbf{0 3}\end{array}$ & $\begin{array}{c}\text { MgC } \\
\mathbf{0 3}\end{array}$ & $\begin{array}{c}\text { Oxyd } \\
\text { es Fe }\end{array}$ & $\begin{array}{c}\text { Silico- } \\
\text { alumino } \\
\text { us } \\
\text { materia } \\
\text { ls }\end{array}$ \\
\hline Karst & $\begin{array}{c}\text { G675D } \\
\text { PM 245 }\end{array}$ & 29 & 1.34 & 6.72 & 55 \\
\hline Karst & $\begin{array}{c}\text { G675D } \\
\text { PM 239 }\end{array}$ & 7 & 0.6 & 16 & 66 \\
\hline Karst & $\begin{array}{c}\text { Dam's } \\
\text { excavation } \\
605\end{array}$ & 27 & 2.6 & 5.6 & 57 \\
\hline Karst & $\begin{array}{c}\text { Dam's } \\
\text { excavation } \\
605\end{array}$ & 12 & 5.8 & 10 & 63 \\
\hline Karst & $\begin{array}{c}\text { G675D } \\
\text { PM 340 }\end{array}$ & 32 & 0.56 & 4.8 & 60 \\
\hline Karst & $\begin{array}{c}\text { G675D } \\
\text { PM 140 }\end{array}$ & 69 & 2.18 & 4.4 & 22 \\
\hline Karst & $\begin{array}{c}\text { G675D } \\
\text { PM 245 }\end{array}$ & 11 & 1.61 & 8.8 & 57 \\
\hline Karst & $\begin{array}{c}\text { G675D } \\
\text { PM 310 }\end{array}$ & 51 & 24 & 0.6 & 21 \\
\hline
\end{tabular}

Table 1. Chemical analyses carried out on karst anomalies to determine the composition of their filling

$30 \%$ of karst anomalies observed have strong concretions, partial blockages (isolated cavities partially filled or grouped cavities, some of which are completely filled while others are empty) or complete blockages. However, hard, well-crystallized concretions are not frequent and are limited to deposits of a few millimeters to a few centimeters and never completely close the opening of the karst.

The brecciated aspect of the deposits of small to medium sized rock fragments sandy sandstones and dolomitic sands, suggests that these materials are not only the result of an alteration in place of dolomitic limestone but also represent sink holes in former cavities.

\subsection{Structural controls}

Structural control consist in an evaluation of the influence exerted by the structural elements of the rock such as stratification joints, faults, diaclases, on the location and orientation of karst ducts, in our case, structural control by faults and fractures must be essentially a local phenomenon because faults and fractures that intersect more than a few banks are rare, the ducts tend from one level to another to be set on different discontinuities, sometimes on very minor and penetrating ones.

a- The role of stratification joints in the orientation and location of karst pipes is certainly important.

- In subhorizontal series, marl joints will simply help to deflect vertical flows.

- In much straightened series, they can concentrate and channel flows much better, this has been observed in particular in the gallery on the left bank. 
b- The fold axes, in particular the synclinal axes, are very clearly areas of privileged circulation, due to a containment effect in one hand and to tensile cracks in the other.

c- In the restitution zone, subhorizontal joints promote the development of a joint karst, with a planar network of stepped ducts, possibly over several levels. The cavities discovered under the bottom of the right bank of the dam represent a typical case of this karst.

d- The largest faults observed during excavations have generally indurated fills that reach or exceed $20 \mathrm{~cm}$ in thickness in some areas and throws in the order of a few decimetres or a maximum of $1 \mathrm{~m}$. In the vicinity of these faults, karst phenomena are infrequent, with low amplitudes and low extensions. All other visible faults and fractures are much smaller, with rarely a centimetric filling; their extension in most cases does not exceed a small number of limestone banks.

e- The FDP fault intersected on the dam axis by bore holes SP10, SP11 and SP12 respectively at 532, 556 and 578 NGM, shows no karstification and the grey-blue color of its cement indicates the good watertightness of this structure, which is also so confirmed by the Lugeon water tests performed in these bore holes.

As a result, we can see that the structural control of karst by stratification joints is the most developed, especially in the highly inclined layers, where they can concentrate and direct flows (control of folds is linked to synclinal axes), and that there are no major fault that can control karst phenomena.

This leads us to see the major interest of the waterproofing membrane under the dam, which will limit any kind of flow that threatens the stability of the structure [12] or particularly at the level of these lateral supports, and to highlight the concentrations of karst passages with in the grout curtain.

\subsection{Statistical analysis}

\subsubsection{Approximation by a normal distribution law:}

A statistical analysis [13-14-15] was carried out on a sample of 45 karsts anomalies from surveys of excavated areas such as dam excavations, access roads and dug tunnels.

These karst anomalies can typically vary in diameter from 0.18 to $5 \mathrm{~m}$ (table 2)

\begin{tabular}{|c|c|c|c|c|c|c|c|c|}
\hline $\begin{array}{c}\text { Hole } \\
\text { diameter } \\
(\mathbf{m})\end{array}$ & 1.2 & 1.25 & 1.5 & 2 & 3 & 3.5 & 4 & 5 \\
\hline $\begin{array}{c}\text { Number of } \\
\text { karsts }\end{array}$ & 1 & 1 & 3 & 3 & 1 & 1 & 1 & 3 \\
\hline
\end{tabular}

\begin{tabular}{|c|c|c|c|c|c|c|c|c|}
\hline $\begin{array}{c}\text { Hole } \\
\text { diameter } \\
\text { (m) }\end{array}$ & 0.18 & 0.2 & 0.3 & 0.4 & 0.5 & 0.7 & 0.8 & 1 \\
\hline $\begin{array}{c}\text { Number } \\
\text { of karsts }\end{array}$ & 1 & 5 & 4 & 2 & 4 & 2 & 8 & 5 \\
\hline
\end{tabular}

Table 2. Karst anomalies from surveys of excavated areas

The graphical analysis of the histogram [16-17-18] of the numerical data represented in figure 2 allowed us to put forward a hypothesis relating to the type of the probability distribution and thus tests whether the empirical sample is in agreement with a given theoretical distribution or whether the gap between this distribution and the empirical one is very large.

Karstic anomalies are grouped in intervals in such a way as to approximate the distribution by a normal distribution $\mathrm{N}(\mu, \sigma)$ defined by two parameters:

- The mean $\mu$

- And the standard deviation $\sigma$

In our case:

Note that:

$$
\begin{array}{ll}
-\mathrm{n}=45 & : \text { total population } \\
-\mathrm{I}=5 & : \text { number of intervals }
\end{array}
$$

The mean and the standard deviation of this distribution have been determined by the formulas:

$$
\mu=\sum_{I} \mathrm{n}_{i} \xi_{\mathrm{i}} / \mathrm{n}
$$

$$
\sigma^{2}=\sum_{I} \mathrm{n}_{i} \xi_{\mathrm{i}}^{2} / \mathrm{n}-\mu^{2}
$$

We have: $\quad \mu=1.07$ and $\sigma=0.52$

Then, we calculate the probabilities noted $\mathrm{Pi}$ associated to our normal distribution using GeoGebra software (Table 3):

\begin{tabular}{|c|c|c|}
\hline Intervals & Population (ni) & Probabilities (Pi) \\
\hline$<\mathbf{0 . 3}$ & 6 & 0.1423 \\
\hline$[\mathbf{0 . 3 , 0 . 8}[$ & 12 & 0.2144 \\
\hline $\mathbf{0 . 8 , 1 . 2}[$ & 3 & 0.2157 \\
\hline$[\mathbf{1 . 2 , 2 . 2}[$ & 8 & 0.3283 \\
\hline$\geq \mathbf{2 . 2}$ & 6 & 0.1003 \\
\hline
\end{tabular}

Table 3. Probabilities of the distribution of karst anomalies by normal distribution $\mathrm{N}$

\subsubsection{Chi square goodness of fit test}

The chi-square goodness of fit test is used to check whether or not the sample comes from the random variable of the normal distribution $\mathrm{N}(\mu, \sigma)$ already defined; the method consists in comparing the frequency histogram and the distribution of the probability 
distribution used as a theoretical model. For this purpose, after having divided the observation interval into I intervals, an index $\mathbf{d}$ is constructed measuring the difference between the observed and theoretical distribution, which is compared under the following hypothesis:

$\mathbf{H}_{\mathbf{0}}$ : The observed distribution is identical to the theoretical distribution « $\mathrm{X}$ »

$\mathbf{H}_{1}$ : The observed distribution is different from the theoretical distribution « $\mathrm{X} »$

The steps of this test are as follows:

1. Calculation of a the theoretical size «n. Pi» in each interval $\mathrm{i}$

2. Verification of the test application conditions

- Total size $\geq 30$

- Theoretical number of employees for each interval $\mathrm{i} \geq 5$

3. Measurement of the observed and theoretical distance $d$ between the two sizes, which is given by the following formula:

$$
\mathrm{d}=\sum_{I}\left[\left(\mathrm{n}_{i}-\mathrm{nP}_{\mathrm{i}}\right)^{2}\right] /\left(\mathrm{n}_{\mathrm{i}}\right) \approx \chi_{\text {obs }}^{2}
$$

Where:

$$
\begin{aligned}
& \mathrm{ni}=\text { observed size of the interval } \mathrm{i} \\
& \mathrm{n}=\text { total observed size } \\
& \mathrm{Pi}=\text { probability of obtaining an observation } \\
& \text { of the theoretical probability law in the } \\
& \text { interval } \mathrm{i} \\
& \mathrm{nPi}=\text { theoretical size of the interval } \mathrm{i} \\
& \mathrm{k}=\text { number of unknown parameters of the } \\
& \text { normal distribution } \mathrm{N}(\mu, \sigma)
\end{aligned}
$$

4. Definition of an error threshold $\alpha=5 \%$ (this means that we have a $5 \%$ risk of rejecting the adjustment hypothesis if it is true, therefore a $95 \%$ of accepting it if it is true).

5. Calculation of the number of degrees of freedom ddl $=\mathbf{I}-\mathbf{k}-\mathbf{1}$

6. Comparison of $\chi_{\text {obs }}^{2}$ with the theoretical $\chi_{\text {I-k-1 }}^{2}$ read in the chi squared law tabulated and available in Appendix A.

In our case: for a risk $\alpha=0.05$ (namely $(1-\alpha$ ) $=0.95)$, the quantile value of the Chi squared law for $\mathbf{d d l}=\mathbf{2}$ degrees of freedom is equal to 5.9915 (see table in Appendix A)

7. Conclusion : if $\chi_{\text {obs }}^{2}<\chi_{\text {I-k-1 }}^{2}$ then the hypothesis is accepted

\section{Results and discussions}

The Chi square fit test is proposed to be performed with the $\mathrm{R}$ Project software, which is a data processing software that allows important statistical calculations to be performed on a large amount of data and their graphical representations to be generated. It is also a programming language with which the chi-square test will be executed as a program:

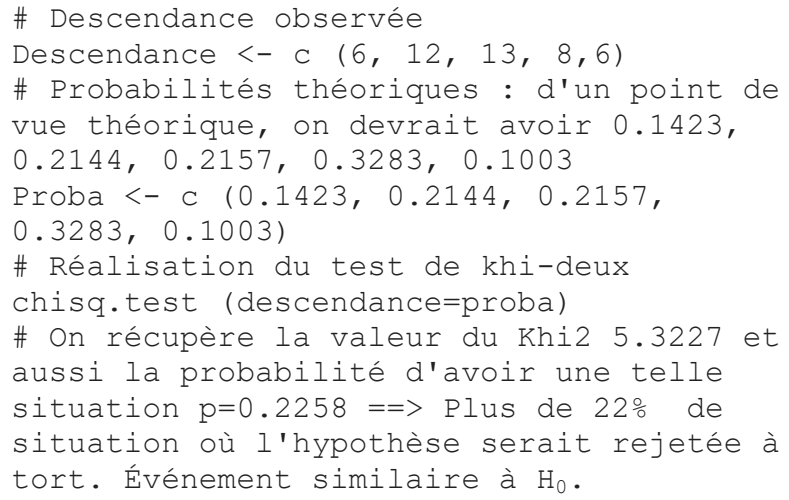

On the other hand, if we calculate using $\chi_{\text {obs }}^{2}$ a spreadsheet, we obtain a value of $\mathbf{5 , 3 1 9}$.

- At the materiality level $\alpha=5 \%$ :

$$
\chi_{\mathrm{I}-\mathrm{k}-1}^{2}=5.9915>\chi_{\mathrm{obs}}^{2}=5.32
$$

So we accept $\mathrm{H}_{0}$, and our distribution follows the normal law $\mathrm{N}(1.07,0.72)$.

\section{Implications for the treatment of the waterproofing veil:}

Statistical analysis of the survey data from the excavated areas made it possible to approximate the distribution (karst diameter) by a normal distribution

$\mathrm{N}(\mu=1.07, \sigma=0.72)$

We can deduce that:

- $47 \%$ of karst have diameters less than $1 \mathrm{~m}$.

- $50 \%$ of karsts have diameters less than $1.07 \mathrm{~m}$.

- $73 \%$ of karsts have diameters less than $1.5 \mathrm{~m}$.

- $90 \%$ of karsts have diameters less than $2 \mathrm{~m}$.

With a spacing distance of $1.1 \mathrm{~m}$ between injection wells, $50 \%$ of karsts will be intercepted by these wells and essentially karsts with diameter greater than $1.1 \mathrm{~m}$. The probability of intercepting small karsts with a diameter $\mathrm{d}$ less than $1.1 \mathrm{~m}$ easily calculated by the formula: $\mathrm{d} / 1.1$

Considering the vertical arrangement of Quaternary karsts with diameters less than $1 \mathrm{~m}$, and the horizontal arrangement in North-South direction of Prequaternary karsts with diameter greater than $2 \mathrm{~m}$, the use of inclined boreholes in the plane of the grout curtain will be essential to increase the probability of intercepting these karsts. We therefore take an angle of $20^{\circ}$ to $30^{\circ}$ from the vertical to multiply the chance of intercepting the grout curtain.

In addition, GIN energy can contribute significantly to the effectiveness of small karst treatment, as the increase in injection energy (without the risk of fracturing the rock) [19] Causes an in increase in the radius on influence and subsequently treats nearby smalls karsts. 


\section{Conclusion}

The use of statistical analysis is proved to be essential to solve intercepting karst's problems related to dams and their grout curtain. As injection drillings has been defined, the appropriate injection process has yet to be determined and the empirical formulas must be adapted according to the first results of the test plots accomplished. However, given the problems encountered in locating karst anomalies in the dam site, the use of the micro-gravity as a geophysical method in parallel with a statistical study is highly recommended to better locate these anomalies in order to perfect their treatment and optimize as much as possible the injection process, which always remains constrained to his execution in the field.

\section{Reference}

1. A.C. Houslby, Construction and design of Cement Grouting, (14 Mai 1990).

2. G. Ballivy, P .Niemants, Nouvelles techniques de reconnaissance en laboratoire pour la conception des rideaux d'étanchéité dans le roc, $14 \mathrm{e}$ congrès des grands barrages, Rio, Brésil (1982).

3. A. Michard, Eléments de Géologie Marocaine, Edition du service géologique du Maroc, Rabat (1976).

4. P.G. Marinos, Dam geology in karstic regions in Greece General aspects and specific case studies, Bulletin of the International Association of Engineering Geology 25: 133-136 (1982).

5. L. Calembert, Engineering geological problems in karstic regions, Bulletin of the International Association of Engineering Geology 12: 93-132 (1975).

6. A. Bouja, Contribution à l'étude de l'injection d'un coulis de ciment en milieu fissuré, Doctorat en Sciences Appliquées, Université de Sherbrooke (1994).

7. G. Lombardi, The role of the cohesion in cement grouting of rock, $15^{\text {th }}$ ICOLD Congress, Lausanne, Switzerland 41 (1985).

8. L. Hässler, U. Hakansson, H. Stille, Computer simulated flow of grouts in jointed rock, Grouting soil improvement and Geosynthetics, ASCE and ISSMFE, New Orleans, La, Vol. 1, pp 461-473, (February 1992).

9. S. Perret, Contribution à l'étude des critères d'injectabilité des coulis de ciment dans les sols fins, national Library of canada, 114 (1997).

10. V. Sicik: Engineering Geology Explorations in karst regions, rapport inédit (Commission AIGI 1974).

11. P. Petiteville, M. Toulemont, Les études de Géologie de l'Ingénieur en régions karstiques; tendances françaises, rapport inédit (Commission AIGI 1974).
12. B. Poupelloz, M. Toulemont, Stabilisation of karstic areas by injection, about the Gipsiferous Lutetium in the region of Paris, Bulletin of the International Association of Engineering Geology 24: 111 (1981).

13. J. Magnan, Les méthodes statistiques et probabilistes en mécanique des sols. Presses des Ponts et chaussées, Paris 1982.

14. G. Simenoi, Analyse statistique des perméabilités ponctuelles des calcaires aquifères du Jura Neuchatelois (Suisse). Actes du deuxième Colloque d'Hydrologie en pays calcaire. Annales Scientifiques de 1'Université de Besançon. Fasc.25, 391-404.

15. K. Baba, L. Bahi, L. Ouadif, C. Cherradi, Multivariate Statistical Analysis tool for the interpretation of geoelectrical data: application to Sterile Bodies in the Sidi Chennane phosphatic deposit (Morocco), J. Mater. Environ. Sci. 5 (4) 1005-1012 (2014).

16. B. Mathey, G. Simenoi, Estimation de la perméabilité en terrain calcaire par essais d'injection d'eau. Actes du Colloque d'Hydrologie en pays calcaire. Annales Scientifiques de l'Université de Besançon. Troisième série, fasc.15, 165-175.

17. K. Bennis, L. Bahi, PCA and Cluster Analysis for criteria mapping in landfill siting, International Journal of Engineering and Technology, Vol 6, Issue 5 page 2244-2260 (2014).

18. M. Ben Tahar, L. Bahi, L.Ouadif, Application of a Multivariate Statistical Analysis tool (PCA) for the Optimisation of Dam Foundation Grouting, International Journal of Engineering and Technology, Vol 6, Issue 7 page 44-52 (2015).

19. G. Lombardi, Aspects spécifiques de l'injection $d u$ massif rocheux (2007).

20. Documentation du Service Géologie d'Exécution des barrages, DAH Rabat. 